\title{
THOMAS WELBOURNE CLARK
}

Thomas Welbourne Clark, who died on 22 December 1969 after a serious operation, was born at Ilkeston in Derbyshire on 2 January 1904. There he attended the County Secondary School, and in 1921 went to read English, with subsidiary Latin, at University College, Nottingham, then affiliated to London University. After graduating he stayed on a year to take the Cambridge Certificate in Secondary School Teaching, and thus equipped as a schoolmaster he joined the Bengal Senior Education Service in 1925. His posting to Victoria School, Kurseong - a boys' boarding-school under the Government of Bengalwas a happy one, for he stayed there, with an interval for war service, until his retirement in 1948 .

In his new country he found much to learn; not only of Bengal, Bengali, and the Bengalis, but also of Nepali, for the Darjeeling district in which Kurseong is situated had a large Nepalese population, and he was not the sort of man to take no interest in his neighbours. Hindi also interested him, for he took the Bengal Higher Standard examination in 1927, although he was more deeply occupied with English studies : on his first furlough, in 1928-9, he returned to Nottingham to work for the London M.A. in English. But by this time India had clearly cast her irrevocable spell over him, and on his return the solid foundations of his spoken and literary fluency were being laid in both Bengali and Nepali, buttressed by a deep appreciation of the cultural context of both languages. He felt, however, that the knowledge he was accumulating needed systematization ; ' my attempts to learn Hindi, Bengali and Nepali [in India] have been frustrated by lack of adequate teaching', he wrote. Accordingly, on his next furlough, in 1934, he took the step which was to influence the rest of his career : he enrolled for courses at the School of Oriental Studies in Finsbury Circus, studying Sanskrit with Mr. Rylands, Indian philology with Professor Turner, and Bengali with the Reverend W. Sutton Page, then Reader in Bengali, whose brilliant teaching was later to be such a source of inspiration to his own.

\section{Doctrina sed vim promovet insitam,}

Rectique cultus pectora roborant :

the 'innate force' was indeed awakened, for all three teachers gave him an A grade on his year's work, and Sutton Page had asked him to assist in the compilation of his great Bengali dictionary by sending back slips from Bengal. Clark later described this time as 'one of the happiest years of my life', and wrote 'I have learned more in three terms' work in the School . . . than I could have done in three years in India '. He now began to spend his vacations among Bengalis, including a month in Tagore's àśram at Śāntiniketan. 'He invited me to sit by his side; and began to talk of my work, why I wanted to learn his language, and how I was progressing. And immediately a relationship was established, that simple Indian relationship of guru and celä.' ${ }^{1}$ In 1938, while

1' Rabindranath, man and boy', a paper he sent from Pennsylvania to be read at the Tagore Centenary Symposium organized at the School on 15 March 1961. 


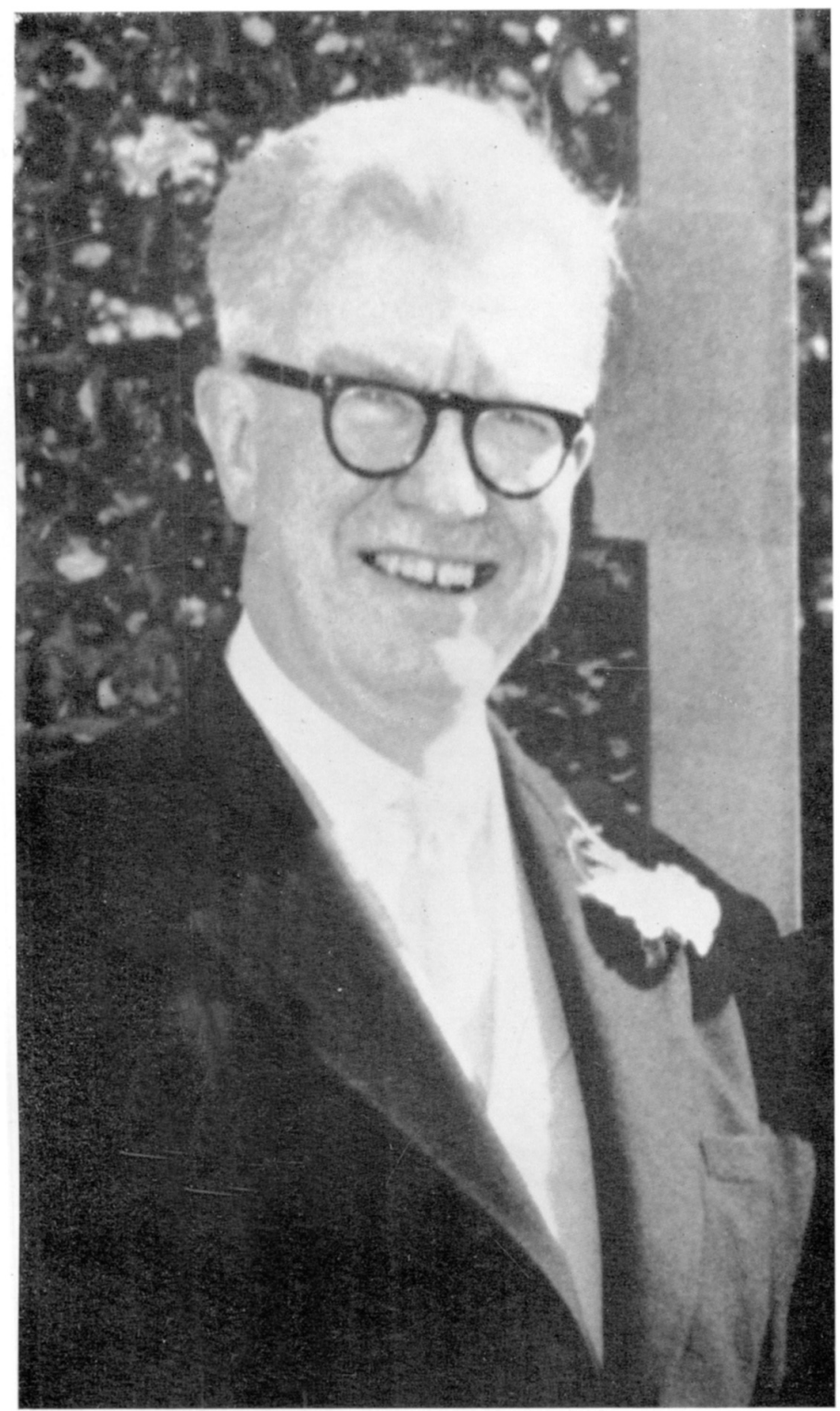

Thomas Welbourne Clark

BSOAS. XXXIII] 
making his plans to return to the School on his furlough the following year ' to have all that I am doing arranged and co-ordinated', he heard of Sutton Page's death, and wrote to Professor Turner, by now Director, 'it seems as if something has been taken out of my life'. The Bengali post that thus fell vacant was advertised, and Clark applied for it-but with reservations, made in an accompanying letter. 'I feel', he wrote, ' that it will be better for me to work for a few years more in India before leaving the country finally.'

In the event he had to decline the offered Senior Lectureship, for he could not afford to face the considerable diminution in salary entailed; but he came, nevertheless, to spend his furlough at the School, working again with Rylands and Turner, and with two new teachers: Miss Summers in Bengali, and Firth in Indian phonetics. He might even then have been persuaded to change his mind about the Bengali post, but that furlough was cut short abruptly: he was called up for service in September 1939 (he had been commissioned in the I.A.R.O. in 1927), and joined the Indian Intelligence Corps ; before long he was commanding the Calcutta Censor Station and the Eastern Army Censorship Zone. He was released, as a Lieutenant-Colonel, in 1946, and was appointed O.B.E. He went back to Victoria School, this time as Headmaster, and was at the same time appointed Inspector to the Government of Bengal on the teaching of Bengali and Hindi in European and Anglo-Indian schools, where he took the opportunity to collect ideas for his own teaching ' based on the phonetic approach to Indian vernaculars and the preparation of early conversation lessons' : the influence of both Sutton Page and Firth is clearly visible here, and it is not too difficult to see the way his thoughts were leading him, for in response to an approach by the School towards the end of 1947 he declared, 'ever since my first period at the School it has been my wish ultimately to return as a member of the staff'.

That wish was granted in 1948, when he retired from the Bengal Senior Education Service and joined the School as Lecturer in Bengali. He threw himself into his new duties with that conscientious and painstaking zeal we came to expect of him ; and not only in Bengali, where he was methodically working on Sutton Page's principles, hiving wisdom with each studious year, but in Nepali also. When I joined him late in the following session to prepare an intensive Nepali course at the request of the War Office I found that this was something he had taken in his stride, and to which he was prepared to give up the whole of the summer vacation: by the time the new session started the entire course had come into being, complete with records - enough to keep our service students busy for four hours a day for a term. But this concentrated exercise in restricted language-regimental Nepali-was not enough for him, and he progressed towards the Nepali of the Valley, helped by his first visit to Kathmandu and by the presence of a member of the distinguished Rana family at the School. The value of this work was recognized by the title of his lectureship being changed to 'Bengali and Nepali' in 1955.

Clark's experience in education led to constant demands for his services on 
committees and boards. He soon became departmental tutor to students of the modern languages, and in 1958 when the School instituted the office of Senior Tutor, " to interview students seeking admission . . . for a first degree and give them general advice to assist them in deciding on their course of study ; and to advise students on careers ', Clark was the obvious man for the job. The strength of his success was that he always had confidence in the young; in cases of doubt he was disposed to give youth its chance, and he was reluctant to see the young student as cereus in vitium flecti, monitoribus asper. This attitude he retained when he took over the headship of the department of India, Pakistan, and Ceylon, when his advice was freely available to anyone who sought it, always carefully considered and always valuable. Clark would hear both sides of an issue in full before making judgment; but that judgment, once made, would be unvacillating.

Clark was invited in 1961 to the University of Pennsylvania, where as Visiting Professor he conducted advanced Bengali classes and also taught the first Nepali classes to be held in an American university. He enjoyed his time there, and after his return he retained a connexion with that university as London adviser to Pennsylvania students working in London in the South Asian field. In 1962 he became the first holder of the established Readership in Bengali (Sutton Page's Readership was by title), and five years later the first occupant of the first Chair of Bengali at a British university. He expressed his delight at the University's recognition of his language (the only major literary language, besides Urdu, common to both India and Pakistan) and at a modern South Asian language being represented at the professorial level. As Professor W. Norman Brown, the doyen of American orientalists, wrote to Clark from Pennsylvania, 'London University deserved a Professorship of Bengali ; and so did you'.

Clark's publications were few, but they were of scrupulous craftsmanship and redolent of a lifetime's experience in the languages he had mastered. For example, his Introduction to Nepali is by far the most authoritative and comprehensive treatment of the language that has yet appeared, as high above the usual 'beginner's grammar' as Milton (one of Clark's loves) is above a popular lyric; and his translation into English of Bibhutibhushan Banerji's novel Pather pañcäli, in collaboration with his colleague and former student Dr. Tarapada Mukherjee, combines in masterly fashion his feeling and love for both English and Bengali, together with an obvious affection for Bengal and its people. He somehow found time to keep up his English reading, and he never lost his love of Latin - as his last Bulletin article revealed.' He had for long been working on a Bengali teaching course, polishing and improving it, and testing it in practice, over several years ; happily, much is already written, and the rest is in an advanced stage of preparation, and it seems that it will be possible to send the work to a publisher before very long.

2 'Meghanädbadhkāeya, canto viii : descensus Averno', BSOAS, xxx, 2, 1967, 337-52. 
His first academic loyalty was always to the School, although the Philological Society interested him deeply, and he served on its Council in 1955-6 and again from 1958 to 1965 . In the School his popularity transcended merely academic bounds. He was always a supporter of the Common Room, of which he had been Chairman, and he was a foundation member of the 49 Dining Club ; both these institutions will remember his laughter, for he had a tremendous sense of fun. We shall remember, too, his interest in the Christian Union ; he conducted several of the lunch-hour and end-of-term services, and was an inspiring preacher. He was a Lay Reader in the dioceses of Calcutta and Southwark, and his faith was a deep and abiding one-the Psalmist's song 'The fear of the Lord is the beginning of wisdom' might well have been his personal motto, for this principle informed his whole life and guided his thought and practice. I quote again from that Tagore lecture : 'I cannot recall any passage in which Rabindranath defined sin ; but if I read him aright I feel sure that he would agree that whatever divides man from man partakes of the nature of sin'. That was Nunkie Clark talking, not Tagore : he saw his whole duty as absorbed in man and in increasing man's understanding. The loss of his scholarship and experience is a grievous blow ; but more than anything his friendsand he had hundreds, not only here but in India, Pakistan, Nepal, and America-will lament the loss of a wise and respected colleague, a staunch friend, a man of vision, of integrity, and above all of a rich humanity.

JOHN BURTON-PAGE 